\title{
Production of Gramicidin S Synthetases by Bacillus brevis in Continuous Culture
}

\author{
By C. C. MATTEO,* C. L. COONEY AND A. L. DEMAIN \\ Department of Nutrition and Food Science, Massachusetts Institute of Technology, \\ Cambridge, Massachusetts 02139, U.S.A.
}

(Received 23 April 1976)

\begin{abstract}
SUMMARY
The effects of different nutrient limitations on the production of the two enzymes of gramicidin S biosynthesis were studied during continuous culture of Bacillus brevis. Gramicidin S synthetases I and II were produced in the chemostat under carbon, nitrogen, phosphorus or sulphur limitation. The growth rate, rather than the nature of the limitation, was the major controlling factor in regulating the level of the gramicidin S synthetases. Synthetase production was low at high dilution rates $\left(0.45\right.$ to $\left.0.50 \mathrm{~h}^{-1}\right)$ but increased as the dilution rate was lowered. The highest specific activities occurred at dilution rates that were different for each type of limitation: $0.40 \mathrm{~h}^{-1}$ for nitrogen, $0.32 \mathrm{~h}^{-1}$ for carbon, $0.24 \mathrm{~h}^{-1}$ for sulphur and $0.20 \mathrm{~h}^{-1}$ for phosphorus. Phosphorus limitation gave the highest specific activities. At low dilution rates $\left(0 \cdot\right.$ I o to $\left.0 \cdot 15 \mathrm{~h}^{-1}\right)$, enzyme activities were again low. Sporulation occurred under carbon limitation, but at a lower dilution rate than that which supported optimal gramicidin S synthetase formation. The specific productivity of the synthetases in the chemostat was higher than the highest productivity obtained in batch growth.
\end{abstract}

\section{INTRODUCTION}

The enzymic formation of the decapeptide antibiotic gramicidin S (GS) has been employed as a model system by the Massachusetts Institute of Technology Interdisciplinary Enzyme Group to explore the potential of preparative-scale cell-free synthesis (Hamilton, Montgomery \& Wang, 1974; Matteo et al., 1975; Tseng et al., 1975). GS was chosen for this project because its biochemical formation by Bacillus brevis is understood and involves only two enzymes. The studies concerned with this biochemical mechanism have recently been reviewed by Laland \& Zimmer (1973) and by Lipmann (1973).

To exploit the ability of $B$. brevis to produce synthetases for use in the enzymic production of GS, we first had to identify the factors regulating the appearance of the enzymes in vivo. The effect of medium composition on enzyme production during batch growth has been reported previously (Matteo et al., 1975; Demain \& Matteo, 1976). In these experiments, synthetase activities appeared for only a short time and then rapidly disappeared, suggesting that a unique set of conditions, which are favourable to GS synthetase appearance and stability, exists, but only for a very short time in the batch growth cycle. Furthermore, the sudden appearance of enzyme activity towards the end of the exponential growth phase suggested that either nutrient limitation or the growth rate was the significant variable in the establishment of favourable conditions.

Chemostat experiments offer the potential for maintaining a unique set of conditions in

* Present address: Union Carbide Corporation, Corporate Research Laboratory, Tuxedo, New York 10987, U.S.A. 
steady state as well as for focusing on nutrient limitation and growth rate as independent variables. The potential also exists for higher productivity of the GS synthetases under steady-state conditions than is observed in batch cultures where enzyme activity appears for only a short time during the growth cycle. Realization of these potentials depends on the identification of optimum conditions for synthetase appearance and stabilization, which can be accomplished in chemostat culture. In this report, we summarize our efforts to explore the correlations between growth rate, nutrient limitation and GS synthetase activities in continuous culture.

\section{METHODS}

Strains. Bacillus brevis ATCC9999, the producer of GS, and Bacillus subtilis ATCC605I, the organism used for assay of GS, were maintained as spore suspensions, as previously described (Matteo et al., 1975). All media used in shake-flask experiments were sterilized for $15 \mathrm{~min}$ at $125^{\circ} \mathrm{C}$. For chemostat experiments, 151 medium was sterilized for $90 \mathrm{~min}$ at $125^{\circ} \mathrm{C}$ in a 201 polypropylene carboy.

Inoculum and production cultures were routinely checked for contamination by microscopic examination. In many cases, cultures were also plated out on Difco Antibiotic Medium no. 2 agar and colonies were examined for sporulation. The production of GS was confirmed by the presence of a zone of growth inhibition around each colony when the plates were overlaid with nutrient agar containing the indicator organism (B. subtilis ATCC605I).

Batch culture. The defined medium (G2T) - which contained glycerol, $\left(\mathrm{NH}_{4}\right)_{2} \mathrm{SO}_{4}$, Tris buffer and inorganic salts - and culture conditions have been described previously (Matteo et al., 1975). In certain cases (see Results), this medium was supplemented with L-amino acids at $0 . \mathrm{I} \%$.

Chemostat cultures. A I 1 fermenter ( $400 \mathrm{ml}$ working volume), as described by Cooney (1970) and modified by Fuchs (1974), was used for continuous-culture experiments. A constant temperature of $37{ }^{\circ} \mathrm{C}$ was maintained by immersing the vessel in a water bath containing a thermostat. The $\mathrm{pH}$ was controlled at 6.8 by adding $2 \mathrm{M}-\mathrm{NaOH}$ with a Radiometer TT I I titrator (Copenhagen, Denmark). Dissolved oxygen was maintained at $65 \pm 6 \%$ saturation by controlled addition of oxygen to the air stream. Oxygen levels were detected by a galvanic probe, whose output was fed to a recorder: a microswitch, mechanically coupled to the recorder, opened a solenoid valve when the pen moved below the set point.

Air flow was maintained between 2 and $31 \mathrm{~min}^{-1}$ at an inlet pressure of $35 \mathrm{kPa}$. The outlet air was bubbled through water to maintain a small positive pressure inside the fermenter, thus decreasing the possibility of contamination.

The basal defined medium for chemostat experiments contained (per 1 distilled water): glycerol, Io g; $\left(\mathrm{NH}_{4}\right)_{2} \mathrm{SO}_{4}, 6 \mathrm{~g} ; \mathrm{KH}_{2} \mathrm{PO}_{4}$ (autoclaved separately), $4.08 \mathrm{~g} ; \mathrm{CaCl}_{2} .2 \mathrm{H}_{2} \mathrm{O}$, $10.3 \mathrm{mg} ; \mathrm{CoCl}_{2} .6 \mathrm{H}_{2} \mathrm{O}, 0.24 \mathrm{mg} ; \mathrm{FeCl}_{3} .6 \mathrm{H}_{2} \mathrm{O}, 0.27 \mathrm{mg} ; \mathrm{MnCl}_{2} .4 \mathrm{H}_{2} \mathrm{O}, 9.9 \mathrm{mg} ; \mathrm{Na}_{2} \mathrm{MoO}_{4}$. $2 \mathrm{H}_{2} \mathrm{O}, 0.24 \mathrm{mg}$; $\mathrm{CuSO}_{4} \cdot 5 \mathrm{H}_{2} \mathrm{O}, 0.25 \mathrm{mg} ; \mathrm{ZnSO}_{4} \cdot 7 \mathrm{H}_{2} \mathrm{O}, \mathrm{I} \cdot 4 \mathrm{mg} ; \mathrm{MgSO}_{4} \cdot 7 \mathrm{H}_{2} \mathrm{O}$, I g; and polyethylene glycol P-2000 (anti-foam agent), $0.04 \mathrm{ml}$. In each experiment, the concentration of one of the main components was decreased to growth-limiting levels, as detailed in Results.

Inocula for the continuous-culture experiments were prepared from plates containing Antibiotic Medium no. 2, which had been inoculated with 300 to 1000 spores and incubated for not more than $18 \mathrm{~h}$ at $37^{\circ} \mathrm{C}$. This short period of incubation prevented sporulation on the plates. Loopfuls of bacteria were streaked on plates containing the chemostat medium with $\mathrm{I} \cdot 5 \%(\mathrm{w} / \mathrm{v})$ agar and $\mathrm{MnCl}_{2}$ lowered to $6 \times \mathrm{IO}^{-7} \mathrm{M}$. Plates were incubated for $24 \mathrm{~h}$, after which bacteria were removed with a sterile spatula, suspended in $10 \mathrm{ml} 0.03 \mathrm{M}$-potassium phosphate 
(pH 7.3) and introduced aseptically into the fermenter, which also contained medium that had a low manganese concentration (this prevented sporulation after transfer to the fermenter). Batch-growth conditions were maintained for 4 to $6 \mathrm{~h}$, and then a medium flow was begun, which yielded a dilution rate of between 0.15 and $0.25 \mathrm{~h}^{-1}$. We confirmed that a particular nutrient was limiting growth by noting the increase in cell density (extinction) after a pulse addition of that nutrient to the fermenter. Under steady-state conditions, samples $(45 \mathrm{ml})$ were taken from the fermenter at intervals of at least $20 \mathrm{~h}$. At dilution rates below $0.22 \mathrm{~h}^{-1}$, we used longer sampling intervals to allow at least four culture volumes to pass through the chemostat. Samples were centrifuged (I5 min at $12000 \mathrm{~g}$ ), and cell pellets were stored frozen at $-20^{\circ} \mathrm{C}$. Refractile spores were counted in the phase-contrast microscope.

GS determination. GS titres of the culture were determined by an agar diffusion assay procedure (Matteo et al., 1975).

Bacterial dry weight determination. Growth was routinely determined by measuring culture turbidity at $660 \mathrm{~nm}\left(E_{660}\right)$. Samples were diluted with distilled water to give $E_{660}$ values of less than $\mathrm{I} \cdot 0$. An extinction of 2.5 was equivalent to $\mathrm{I} g$ bacterial dry $\mathrm{wt} / \mathrm{l}$.

Assay of GS synthetase activities. Cell-free extracts were prepared by lysozyme digestion. The enzyme activity was measured by ATP-pyrophosphate exchange, as stimulated by L-ornithine or D-phenylalanine (Matteo et al., 1975). The activity stimulated by L-ornithine represents GS synthetase I (the 'heavy' synthetase), whereas the D-phenylalanine-dependent activity represents GS synthetase II (the 'light' synthetase). One unit of activity is that amount which catalyses the incorporation of $\mathrm{I} n \mathrm{nmol}$ of ${ }^{32} \mathrm{PP}_{\mathrm{i}}$ into ATP in I min. Specific activities are expressed as units/mg protein in the enzyme preparation. Total activities refer to units/l original culture medium.

Protein determination. The protein content of the enzyme solutions was measured by the optical method of Warburg \& Christian as described by DeMoss \& Bard (1957).

\section{RESULTS}

\section{Dynamics of GS synthetases in batch culture}

The appearance of GS synthetases was examined in three different media: G2T; G2T plus $0 . \mathrm{I} \% \mathrm{~L}$-phenylalanine; and G2T plus L-phenylalanine, L-leucine, L-ornithine, L-proline and L-valine, all at $0.1 \%$. The two synthetases appeared towards the end of exponential growth, and their production seemed to be co-ordinated, i.e. GS synthetase I appeared and reached its peak specific activity at the same time as did GS synthetase II. Both synthetases disappeared rapidly after reaching their peak specific activity. The specific growth rates $\left(\mathrm{h}^{-1}\right)$ at the time of highest enzyme activity were $0.21,0.17$ and 0.21 respectively for the three media. Maximum growth rates in these same media were $0.48,0.52$ and $0.4 \mathrm{I} \mathrm{h}^{-1}$ respectively. To determine whether this appearance of synthetase activity was due to exhaustion of a medium ingredient or to the low growth rate itself, we undertook the following chemostat studies.

\section{Chemostat studies}

Carbon-limited growth. Experiments were first carried out to characterize the behaviour of the GS-synthesizing system under carbon limitation. The inflow glycerol concentration in the basal defined medium was decreased to $2 \mathrm{~g}^{-1}$, and the effect of changing the growth rate on enzyme activities was determined. The presence of refractile spores was monitored, since sporulation of $B$. subtilis had been observed under such a limitation by Dawes \& Mandelstam (1970) and by Dawes \& Thornley (1970). 


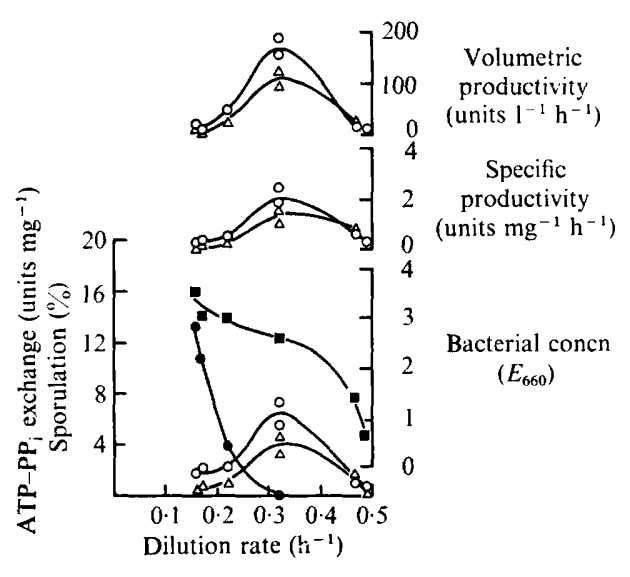

Fig. I

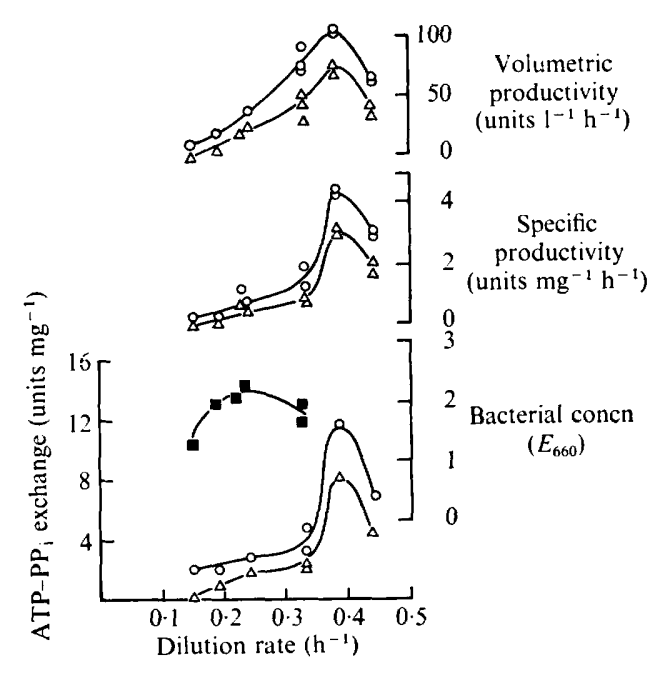

Fig. 2

Fig. I. Enzyme levels, sporulation, productivity and bacterial density at different dilution rates under carbon-limited growth in the chemostat (glycerol at $2 \mathrm{~g} \mathrm{I}^{-1}$ ). $O$, GS synthetase I; $\triangle$, GS synthetase II; $\mathbf{O}$, refractile spores; $\mathbf{a}$, concentration of bacteria.

Fig. 2. Enzyme levels, productivity and bacterial density at different dilution rates under nitrogenlimited growth in the chemostat (ammonium sulphate at $0.6 \mathrm{~g}^{-1}$ ). Symbols as in Fig. I.

As the dilution rate was decreased from the maximum to $0.32 \mathrm{~h}^{-1}$ (Fig. I), steady-state enzyme activities increased to a peak of about 7 units $\mathrm{mg}^{-1}$ for GS synthetase I and 4 units $\mathrm{mg}^{-1}$ for GS synthetase II. The highest dilution rate, $0 \cdot 49 \mathrm{~h}^{-1}$, was obtained during slow washout of the culture. Enzyme activities decreased as the dilution rate was lowered below $0.32 \mathrm{~h}^{-1}$. The percentage of refractile spores increased with decreasing growth rate, from less than $0.1 \%$ at $0.32 \mathrm{~h}^{-1}$ to $13.5 \%$ at $0.16 \mathrm{~h}^{-1}$.

The specific productivity (units $\mathrm{mg}^{-1} \mathrm{~h}^{-1}$ ) and the volumetric productivity (units $\mathrm{l}^{-1} \mathrm{~h}^{-1}$ ) of the synthetases both showed a peak at $0.32 \mathrm{~h}^{-1}$. These two sets of values were derived from the actual amounts of enzyme extracted from the cells, normalized to either the protein content of the sample (specific productivity) or the volume of the sample (volumetric productivity). Specific productivity was independent of the total cell mass.

Nitrogen-limited growth. To determine whether the above behaviour was characteristic of carbon limitation or of a changing growth rate, we explored the relationship between enzyme activity and dilution rate under nitrogen limitation. The ammonium sulphate level in the medium was decreased to $0.6 \mathrm{~g} \mathrm{1}^{-1}$, and the enzyme activities again showed a peak (Fig. 2). Maximum activities of GS synthetase I (I I units $\mathrm{mg}^{-1}$ ) and GS synthetase II (8 units $\mathrm{mg}^{-1}$ ) occurred at a dilution rate of $0.38 \mathrm{~h}^{-1}$. Higher and lower growth rates resulted in a decrease in enzyme activities. Bacteria growing at the two highest dilution rates aggregated. Unlike the results obtained under carbon limitation, no refractile spores (less than $0.1 \%$ ) were detected.

Peak specific productivity ( 4 and 3 units $\mathrm{mg}^{-1} \mathrm{~h}^{-1}$ for GS synthetases I and II, respectively) occurred at the same dilution rate as the specific activity peak. The maximum volumetric productivity also occurred at $0.38 \mathrm{~h}^{-1}$, but did not fall off as sharply as the specific productivity. This finding may reflect the increased cell density at lower growth rates, but because of the aggregation of cells in the culture, we could not determine $E_{660}$ values at the 


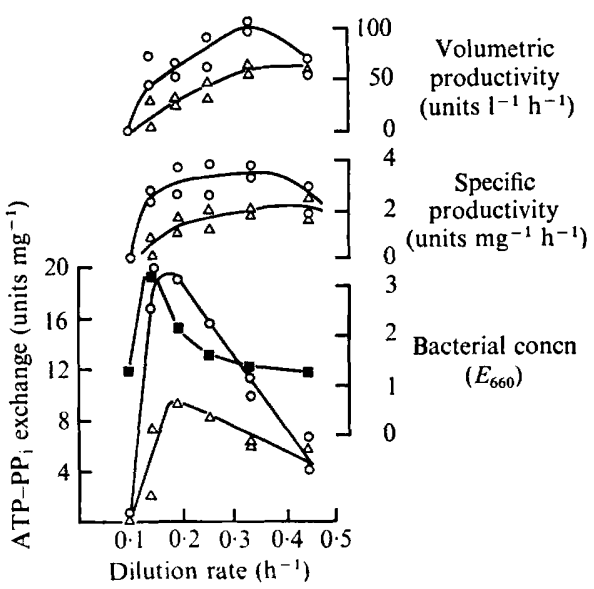

Fig. 3

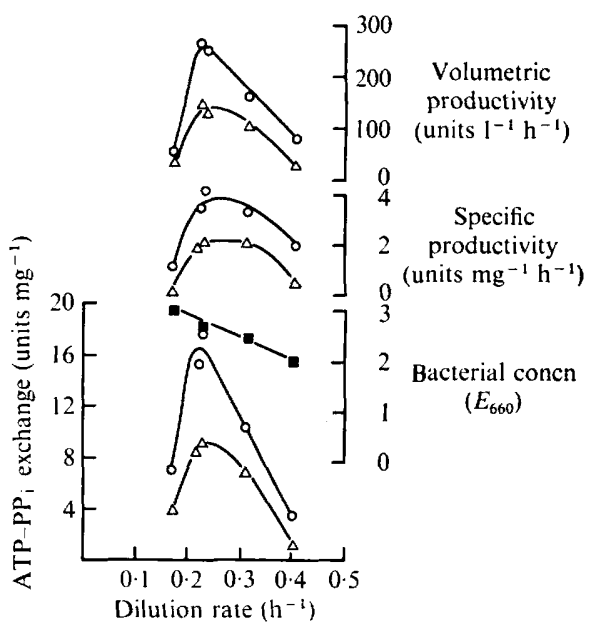

Fig. 4

Fig. 3. Enzyme levels, productivity and bacterial density at different dilution rates under phosphoruslimited growth in the chemostat $\left(\mathrm{KH}_{2} \mathrm{PO}_{4}\right.$ at $\left.0.4 \mathrm{~g} \mathrm{l}^{-1}\right)$. O, GS synthetase I; $\triangle$, GS synthetase II; $\square$, concentration of bacteria.

Fig. 4. Enzyme levels, productivity and bacterial density at different dilution rates under sulphurlimited growth in the chemostat $\left(\mathrm{Na}_{2} \mathrm{SO}_{4}\right.$ at $0.02 \mathrm{~g} \mathrm{l}^{-1}$; all other sulphates replaced by chlorides). Symbols as in Fig. 3.

higher growth rates. The decrease in cell density at the lowest tested dilution rate would not normally be expected (Tempest \& Dicks, 1967) and may reflect the activity of lytic enzymes, which are common in bacilli growing at low rates (Schaeffer, 1969).

Phosphorus-limited growth. With $\mathrm{KH}_{2} \mathrm{PO}_{4}$ at $0.4 \mathrm{~g}^{-1}$, growth was limited by phosphorus and, once again, enzyme activities rose to a peak as a function of dilution rate (Fig. 3). The peak occurred at a lower dilution rate than under carbon or nitrogen limitation and the maximum specific activities (I9 and 9 units $\mathrm{mg}^{-1}$ for GS synthetases I and II, respectively) were higher than under carbon or nitrogen limitation. Limited sporulation $(3 \%)$ was observed at $0.14 \mathrm{~h}^{-1}$. Less than $0.5 \%$ refractile spores were observed at dilution rates of 0.19 and $0 \cdot \mathrm{IO} \mathrm{h}^{-1}$. As with nitrogen-limited growth, a decrease in cell density was noted at the lowest dilution rate tested and may reflect the presence of lytic enzymes.

However, the pattern of enzyme productivity obtained under phosphorus limitation was different from that under the two previous limitations. The specific productivity was fairly constant over a wide range of growth rates (about 3 units $\mathrm{mg}^{-1} \mathrm{~h}^{-1}$ for GS synthetase I and 2 units $\mathrm{mg}^{-1} \mathrm{~h}^{-1}$ for GS synthetase II), and there was no peak corresponding to the peak in specific activity. The volumetric productivity-derived from the measured amount of extractable enzyme per litre of culture - showed a peak at a dilution rate of $0.33 \mathrm{~h}^{-1}$. This dilution rate was much higher than the rate for peak specific activity and probably resulted from the decreased amount of extractable protein per unit volume of culture grown at the lower dilution rates. Thus, the bacteria seem to become more resistant to extraction at lower dilution rates under phosphorus limitation.

Sulphur-limited growth. It was possible that carbon, nitrogen and phosphorus limitations might all be affecting the availability of compounds such as nucleotides, thereby producing similar effects. Sulphur limitation should primarily affect sulphur-containing amino acids, and was therefore tested. 
In the basal medium $\left(\mathrm{NH}_{4}\right)_{2} \mathrm{SO}_{4}$ and $\mathrm{MgSO}_{4} \cdot 7 \mathrm{H}_{2} \mathrm{O}$ were replaced by equimolar concentrations of the corresponding chlorides. Sulphur was provided as $\mathrm{Na}_{2} \mathrm{SO}_{4}\left(20 \mathrm{mg} \mathrm{l^{-1 }}\right)$. The variation of enzyme activities as a function of dilution rate (Fig. 4) resembled the variation found under phosphorus limitation. Enzyme activities reached a peak ( 17 and 9 units $\mathrm{mg}^{-1}$ for GS synthetases I and II, respectively) at a dilution rate of $0.23 \mathrm{~h}^{-1}$. No refractile spores were detected at any dilution rate tested.

Specific productivity appeared to be relatively constant ( 4 and 2 units $\mathrm{mg}^{-1} \mathrm{~h}^{-1}$ for GS synthetases I and II, respectively) between 0.22 and $0.32 \mathrm{~h}^{-1}$. The volumetric productivity peaked at the same dilution rate as the specific activity $\left(0 \cdot 23 \mathrm{~h}^{-1}\right)$ and did not show a plateau.

\section{DISCUSSION}

When a bacterium is removed from one environment and placed in another, its composition changes towards an optimum physiological state, and the concentrations of various enzymes are adjusted by appropriate control mechanisms. Chemostat studies indicate that bacteria grown under different nutrient limitations have different metabolic demands and activities (Tempest, Hunter \& Sykes, 1965; Tempest, Meers \& Brown, I970; Shehata \& Marr, 197I; Smith \& Dean, 1972; Acevedo \& Cooney, 1973, 1975; Cooney, Wang \& Mateles, 1976). Thus the use of selected nutrient limitations offers a means of controlling the enzyme composition of the bacterium, and, by choosing an appropriate growth environment, the investigator can often force the cell to produce, selectively, large amounts of specific enzymes (Pardee, 1969; Demain, 1972 $a, b$ ).

We examined the GS biosynthetic system to elucidate the factors controlling enzyme synthesis. Since GS has no known function in the cell, our approach was to examine the effects on enzyme synthesis of gross changes in the cellular environment. Under batchgrowth conditions (Matteo et al., I975), the peak of transient activity of GS synthetases I and II and the timing of its appearance suggested, first, that the appearance of the enzyme was affected either by the growth rate or by the exhaustion of a specific nutrient or metabolite and, secondly, that the enzyme activity disappeared actively. This second point was supported by the observation that the decrease in enzyme activity after it had peaked was faster than could be accounted for by dilution alone.

In the chemostat steady-state enzyme levels were monitored as a function of growth rate under a number of different specific nutrient limitations. In all cases, a peak in the steadystate enzyme activity was obtained at some rate below the maximum growth rate. The particular growth rate at which the peak occurred depended on the nature of the limitation, indicating that the growth rate, rather than the specific limitation, was the controlling factor in regulating the level of the synthetases in the chemostat. The level of GS synthetases may, however, be determined partly by enzyme degradation. The mechanism of this degradation is not yet known. Preliminary experiments indicate that at least part of the inactivation in vivo is oxygen dependent and irreversible (Demain et al., 1976). Since the net rates of synthesis in the chemostat exceed the highest enzyme specific productivity obtained in batch cultures (Table I), it is clear that preventing enzyme degradation would be an important step in maximizing the yield of the GS synthetases.

In our studies, GS synthetase formation was independent of the ultimate appearance of refractile spores. In the chemostat, GS synthetase activities were observed under all limitations - including both nitrogen and sulphur, which did not result in spore production. When spores did appear, their concentration could be substantially diminished by increasing the steady-state growth rate, a treatment which increased the GS synthetase levels significantly. 
Table I. Comparison of GS synthetase productivity: batch and chemostat growth

\begin{tabular}{|c|c|c|}
\hline Condition & $\begin{array}{l}\text { GS synthetase I productivity* } \\
\text { (units } \mathrm{mg}^{-1} \mathrm{~h}^{-1} \text { ) }\end{array}$ & $\begin{array}{l}\text { Dilution rate for } \\
\text { productivity }\end{array}$ \\
\hline \multicolumn{3}{|c|}{ Chemostat limitation } \\
\hline Carbon & $2 \cdot 4$ & 0.32 \\
\hline Nitrogen & $4 \cdot 4$ & 0.38 \\
\hline Phosphorus & 3.5 & 0.33 \\
\hline Sulphur & $3 \cdot 7$ & 0.22 \\
\hline \multicolumn{3}{|c|}{ Batch-growth medium } \\
\hline G2T & $2 \cdot 6$ & - \\
\hline $\mathrm{G} 2 \dagger$ & 0.5 & - \\
\hline G2T + Phe & $3 \cdot 0$ & - \\
\hline $\mathrm{YP} \dagger$ & $3 \cdot 4$ & 一 \\
\hline
\end{tabular}

* Batch productivity values assume an $8 \mathrm{~h}$ turnaround time between batches.

$\dagger$ Results from Matteo et al. (I975).

Although we were successful in producing GS synthetases in continuous culture, we did not observe production of detectable levels of GS (over Io $\mathrm{mg} \mathrm{l}^{-1}$ ) under any limitation. This low yield was probably caused by the absence of the stimulatory amino acid L-phenylalanine (Demain \& Matteo, 1976) from the medium and by the low cell density (usually less than $\mathrm{I} g$ dry wt $\mathbf{1}^{-1}$ ). Even when the chemostat apparatus and medium were used for batch culture and the air was enriched with oxygen to increase cell growth, the chemostat medium supported GS production only to the degree of $14 \mathrm{mg}$ ( $\mathrm{g}$ dry wt $)^{-1}$. Blanch \& Rogers (I97I) reported GS production in the chemostat, but we cannot compare our results with theirs because they used a complex medium and a non-biological assay of GS, which we did not find satisfactory.

The authors gratefully acknowledge the support of the National Science Foundation for grant GI-34284 and for a predoctoral fellowship to C. C.M.

This paper is contribution no. 2950 from the Department of Nutrition and Food Science, Massachusetts Institute of Technology.

\section{REFERENCES}

ACEvedo, F. \& Cooney, C. L. (I973). Penicillin amidase production by Bacillus megaterium. Biotechnology and Bioengineering $15,493-503$.

ACEVEDO, F. \& COONEY, C. L. (1975). Penicillin amidase and penicillinase production in nitrogen and sulfur limited chemostats. European Journal of Applied Microbiology 2, 9-1 7.

Blanch, H. W. \& Rogers, P. L. (I97I). Production of gramicidin S in batch and continuous culture. Biotechnology and Bioengineering 13, 843-864.

CooneY, C. L. (1970). Double nutritional deficiencies in continuous microbial culture. Ph.D. thesis, Massachusetts Institute of Technology, Cambridge, Massachusetts, U.S.A.

CoONEY, C. L., WANG, D. I. C. \& MATELES, R. I. (1976). Growth of Enterobacter aerogenes in a chemostat with double nutrient limitations. Applied and Environmental Microbiology 3r, $9 \mathrm{r}-98$.

DAWES, I. W. \& MANDELSTAM, J. (I970). Sporulation of Bacillus subtilis in continuous culture. Journal of Bacteriology 103, 529-535.

Dawes, I. W. \& THORNLEY, J. M. M. (1970). Sporulation in Bacillus subtilis. Theoretical and experimental studies in continuous culture systems. Journal of General Microbiology 62, 49-66.

Demain, A. L. $(1972 a)$. Cellular and environmental factors affecting the synthesis and excretion of metabolites. Journal of Applied Chemistry and Bintechnology 22, 345-362.

DemaIn, A. L. (1972 b). Theoretical and applied aspects of enzyme regulation and biosynthesis in microbial cells. Biotechnology and Bioengineering Symposium no. 3, $21-32$.

Demain, A. L. \& Matteo, C. C. (I976). Phenylalanine stimulation of gramicidin S formation. Antimicrobial Agents and Chemotherapy 9, 1000-1003. 
Demain, A. L., Piret, J. M., Friebel, T. E., Vandamme, E. J. \& Matteo, C. C. (i976). Studies on Bacillus brevis directed towards the cell-free synthesis of gramicidin S. In Microbiology-I976. Edited by D. Schlessinger. Washington: American Society for Microbiology.

DeMoss, R. D. \& BARd, R. C. (1957). Physiological and biochemical technics. In Manual of Microbiological Methods, pp. I79-I 8I. Edited by M. J. Pelczar, Jr. New York: McGraw-Hill.

FuCHS, R. (1974). Utilization of mixed substrates by mixed cultures in continuous culture. Ph.D. thesis, Massachusetts Institute of Technology, Cambridge, Massachusetts, U.S.A.

Hamilton, B. K., Montgomery, J. P. \& WANG, D. I. C. (1974). Enzyme reactions for preparative scale synthesis. In Enzyme Engineering, vol. 2, pp. I53-159. Edited by E. K. Pye and L. B. Wingard, Jr. New York: Plenum Press.

LAlAND, S. G. \& Zimmer, T. L. (I973). The protein thiotemplate mechanism of synthesis for the peptide antibiotics produced by Bacillus brevis. In Essays in Biochemistry, vol. 9, pp. 32-57. Edited by P. N. Campbell and G. D. Greville. London: Academic Press.

LipmanN, F. (1973). Nonribosomal polypeptide synthesis on polyenzyme templates. Accounts of Chemical Research 6, 36I-367.

Matteo, C. C., Glade, M., Tanaka, A., Piret, J. M. \& Demain, A. L. (1975). Microbiological studies on the formation of gramicidin S synthetases. Biotechnology and Bioengineering I7, I 29-142.

PARDEe, A. R. (1969). Enzyme production by bacteria. In Fermentation Advances, pp. 3-14. Edited by D. Perlman. New York: Academic Press.

SCHAEFFER, P. (1969). Sporulation and the production of antibiotics, exoenzymes and exotoxins. Bacteriological Reviews 33, 48-7I.

Shehata, T. E. \& MARR, A. G. (I97I). Effect of nutrient concentration on the growth of Escherichia coli. Journal of Bacteriology 107, 2 I0-21 6.

Smith, R. W. \& DeAN, A. C. R. (1972). $\beta$-Galactosidase synthesis in Klebsiella aerogenes growing in continuous culture. Journal of General Microbiology 72, 37-47.

TEMPEST, D. W. \& Dicks, J. W. (I967). Inter-relationships between potassium, magnesium, phosphorus and ribonucleic acid in the growth of Aerobacter aerogenes in a chemostat. In Microbial Physiology and Continuous Culture, pp. 140-I 54. Edited by E. O. Powell, C. G. T. Evans, R. E. Strange and D. W. Tempest. London: HMSO.

TEMPEST, D. W., Hunter, J. R. \& Sykes, J. (I965). Magnesium-limited growth of Aerobacter aerogenes in a chemostat. Journal of General Microbiology 39, 355-366.

Tempest, D. W., Meers, J. L. \& BROWN, C. M. (1970). Influence of environment on the content and composition of microbial free amino acid pools. Journal of General Microbiology 64, 17 I-I 85 .

Tseng, C. H., Thrasher, K. D., Montgomery, J. P., Hamilton, B. K. \& Wang, D. I. C. (I975). High productivity tank fermentation for gramicidin $\mathrm{S}$ synthetases. Biotechnology and Bioengineering $\mathbf{1 7}$, I43-I 5 I. 